\title{
Physiography and recent sediment distribution of the Celtic Deep-Sea Fan, Bay of Biscay
}

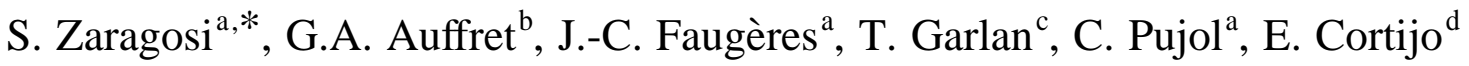 \\ ${ }^{a}$ Département de Géologie et Océanographie, Université de Bordeaux I, UMR 5805 EPOC, 33405 Talence Cedex, France \\ ${ }^{\mathrm{b}}$ IFREMER, DRO/GM, Laboratoire Environnements Sédimentaires, BP70, 29280 Plouzané Cedex, France \\ ${ }^{\mathrm{c}}$ SHOM, Centre Hydrographie, BP 426, 29275 Brest Cedex, France \\ ${ }^{\mathrm{d}}$ Centre des faibles Radioactivités, Laboratoire mixte CNRS/CEA, 91198 Gif sur Yvette, France
}

Received 9 November 1999; accepted 10 May 2000

\begin{abstract}
The Celtic Deep-Sea Fan located in the northwestern part of the Bay of Biscay is a middle sized fan with a surface area of more than $30,000 \mathrm{~km}^{2}$. The whole system is a mature mud/sand-rich submarine fan on a passive margin.

Multi-beam echo sounder data, $3.5 \mathrm{kHz}$ seismic and 12 Küllenberg cores were examined to define the fan morphology, the lithological characteristics, the sedimentary processes and the relationship between the evolution of the fan deposits and the environmental conditions on the Celtic continental shelf.

The upper fan is characterised by the presence of two distinct tributary systems: (1) the Whittard system with a large, persistent, slightly sinuous channel, which is linked to the southern end of the Irish Sea River system; and (2) the Shamrock system, with a moderate sized channel, which is linked to the western end of the English Channel River system. The middle and lower fan corresponds to divergent braided secondary channels and associate lobes. Successive lobe elements, without important relief, were generated during periodic avulsions of middle fan channels.

The lithological, palaeontological, and geochemical analyses on cores show the evolution of sedimentation since the last glaciation. During the last lowstand and rise of sea-level frequent low-density turbidity currents were predominant and deposited sediments throughout the whole fan system. They were initiated at the front of a deltaic environment on the Celtic outer-shelf. During the high sea-level conditions, occasional high-density turbidity currents and/or non-cohesive debris flows occur and were responsible for sand deposition in the middle-lower fan. They are derived from reworked sands due to the highenergy conditions on the outer shelf. Thus for the Celtic Fan, the variations of the hydrodynamic conditions on the outer Celtic Shelf seem to be the primary control on facies shift and fan growth. () 2000 Elsevier Science B.V. All rights reserved.
\end{abstract}

Keywords: Bay of Biscay; Deep-Sea fans; Physiography; Sedimentary processes; Turbidity currents; Quaternary

\section{Introduction}

\subsection{Statement of problem}

Research on modern deep-sea fans is one of the best

\footnotetext{
* Corresponding author. Fax: +33-5-56-84-08-48.

E-mail address: s.zaragosi@geocean.u-bordeaux.fr (S. Zaragosi).
}

ways to improve our knowledge of the sedimentary processes, which are involved in the building of turbidite systems. Comparisons between recently mapped fans and those largely documented in the literature e.g. Indus Fan (Kolla and Coumes, 1987; Kenyon et al., 1995), Mississippi Fan (Bouma, 1985; Bouma et al., 1989; Weimer, 1990; Twichell et al., 1991; Schwab et al., 1996), Amazon Fan 


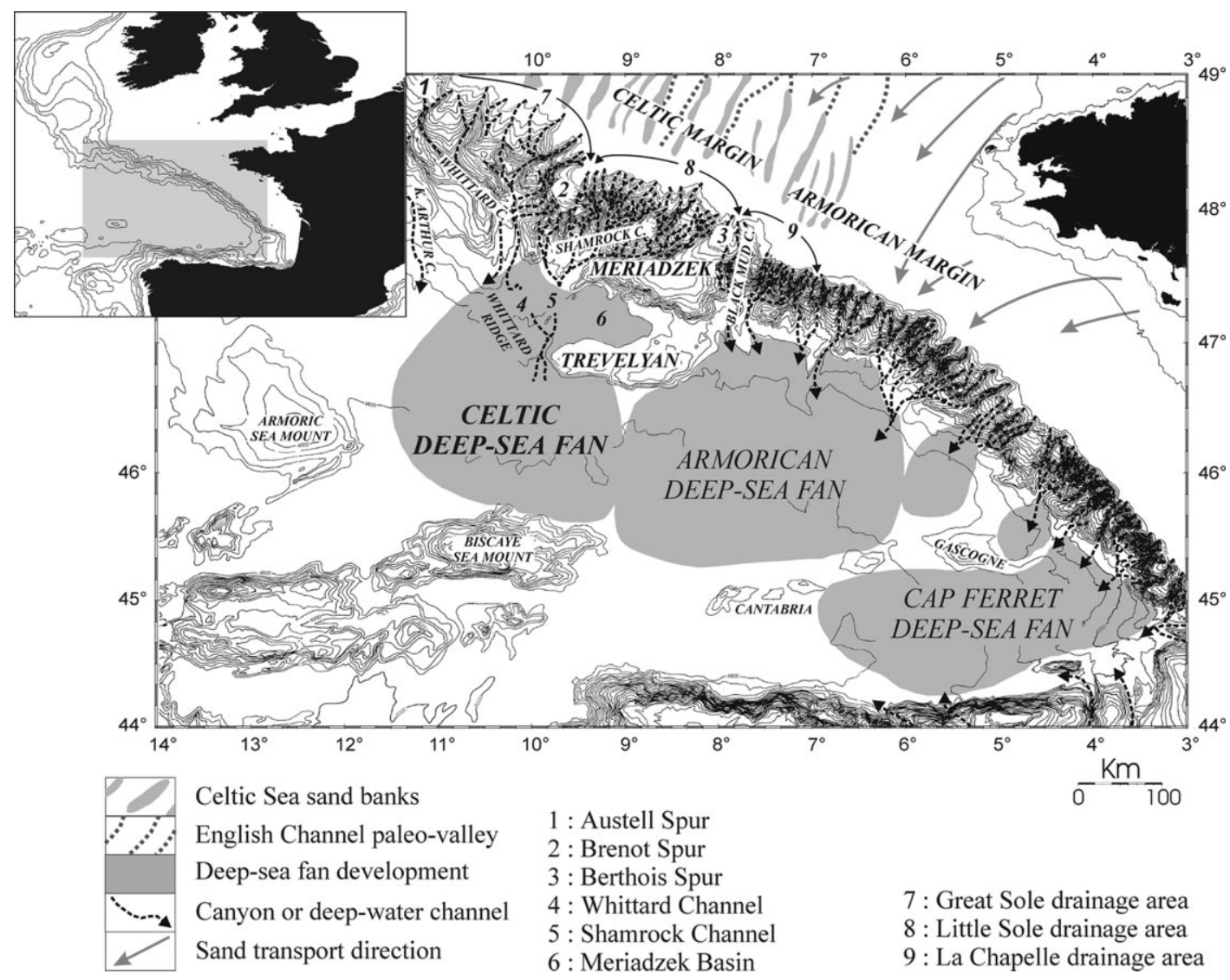

Fig. 1. Bathymetry and morphological setting of the Bay of Biscay. Bathymetry after Sibuet et al. (1994). Sand transport direction after Kenyon and Stride (1970).

(Damuth and Flood, 1985; Damuth et al., 1988; Flood and Piper, 1997), Zaire Fan (Droz et al., 1996) are of major interest for the improvement of submarine fan models. In addition studies of modern turbidite systems bring important information on sea-level changes, sediment flux to the deep oceans, ocean circulation, and regional and global climate variations (Flood and Piper, 1997). Moreover, fan environments are preferential depositional areas on the margins with particularly high sedimentation rates and may offer a high resolution sedimentary record of these variations. The Celtic Fan (Fig. 1) recently mapped in the Bay of Biscay (Droz et al., 1999; Auffret et al., 2000), provides an opportunity to investigate a deep depositional system, disconnected from direct fluvial input, in relation to the palaeoenvironmental evolution of the Celtic margin.
After the previous works of Reid and Hamilton (1990), the first important studies of the Celtic Fan were initiated in 1996 by the SHOM and IFREMER institutes. The complete survey of the area by IFREMER was completed in 1997 (Auffret et al., 2000) in the framework of the ENAM II European programme (MAST 3). One of the major objectives of this programme was to study the evolution of the sedimentary fluxes along the eastern European North Atlantic Margin.

This work complements the recent studies on the English Channel system and the Celtic Continental Shelf (Lericolais et al., 1995; Lericolais, 1997; Reynaud et al., 1999a-d), and on the outer shelf and continental slope (Bourillet and Loubrieu, 1995).

In the present study a large set of data available on the area (Multi beam echo sounder data, $3.5 \mathrm{kHz}$ 
seismic and Küllenberg cores) has been examined in order to address three main objectives:

1. overall fan morphology and subdivisions;

2. lithological characteristics and sedimentary processes of the different environments;

3. relationship between the evolution of the fan deposits, the sea-level change, and the climatic and environmental changes on the Celtic Continental Shelf.

\subsection{Regional setting}

The Bay of Biscay is a passive margin containing three main deep-sea fans (Fig. 1). The Cap Ferret Fan to the South (Cremer et al., 1985), the Armorican Fan in the central part of the bay (Le Suavé, 2000), and the Celtic Fan in the northwestern part. The Celtic Fan extending southward, is bounded to the east by the Trevelyan Escarpment and the Armorican Fan, to the south by the Biscay Sea Mount, and to the west by the Biscay Abyssal Plain. It lies at the foot of the Celtic Continental Margin between 4200 and $4900 \mathrm{~m}$ water depth. The fan is approximately $200 \mathrm{~km}$ long and $250 \mathrm{~km}$ wide and spreads over more than $30,000 \mathrm{~km}^{2}$. Its activity began in the Miocene and its present morphology was developed during a relatively stable tectonic context (Droz et al., 1999). The fan is connected with the Celtic margin slope by two major deep-water channels: (1) the Whittard Channel which is supplied by the Great Sole drainage area linked to the southern end of the Irish Sea system (Fig. 1); (2) the Shamrock Channel which is supplied by the Little Sole drainage area linked to the western end of the English Channel system (Kenyon et al., 1978; Sibuet et al., 1994; Bourillet and Loubrieu, 1995).

The Berthois Spur, prolonged by the Meriadzek Terrace and the Trevelyan Escarpment, is a morphological boundary between the Celtic Margin and the Armorican Margin (Fig. 1). This feature splits the shelf supply between the Celtic Fan and the Armorican Fan.

At present, high-energy hydrodynamical conditions on the Celtic Shelf (storm and spring tidal currents) are able to transport sediment from the near shore areas to the margin slope (Kenyon and Stride, 1970; Johnson et al., 1982; Reynaud et al., 1999d).
Moreover the Celtic Sea sand banks located on the outer shelf constitute a large volume of sandy material, which is subject to reworking. These elongated, parallel banks oriented at right angles to the shelf break are up to $35 \mathrm{~m}$ high, 5-7 km wide and $40-$ $180 \mathrm{~km}$ long. The processes, which have controlled their deposition, are still uncertain: erosional remnants of lowstand nearshore deposits (Berné et al., 1998; Marsset et al., 1999) or totally reworked transgressive shelf deposits (Reynaud et al., 1999b). Whatever the case, these banks are located at the front of a former lowstand estuarine or deltaic system. Indeed, at the end of the Marine Isotope Stage 3 (MIS 3) and throughout the MIS 2, the English Channel was a large alluvial plain flooded by a large river, the so-called Channel River. This river was formed by the confluence of most of the northwest European rivers (Rhine, Meuse, Thames, Solent, Somme, Seine,...) (Gibbard, 1988; Lericolais, 1997). During this period, a broad delta was developed at the outflow of this river (Berné et al., 1998). The last sea-level lowstand never allowed the connection between the river and the canyon heads as shown by the present $120 \mathrm{~m}$ isobath on the Celtic Margin, which is about $150 \mathrm{~km}$ from the shelf break. Despite the impossibility of direct connection, the NE-SW direction of the Celtic Sea sand banks and the English Channel Palaeo-Valley (Fig. 1) associated with tidal currents presumed about twice as strong as those at present during low sea-level conditions (Belderson et al., 1986) suggest a major NE-SW trend for the supply transport to the deep ocean since the last lowstand of sea-level.

\section{Material and methods}

\subsection{Acoustic mapping}

The bathymetry and acoustic imagery are provided from the multibeam echosounder (SIMRAD EM12) survey of the fan conducted on the R/V Atalante (IFREMER) during the cruises SEDIFAN 1 and 2 (Auffret et al., 2000) and on the R/V Esperance (SHOM) during several cruises. On the multibeam echosounder images (Fig. 2b), lighter areas indicate low acoustic backscatter and darker areas indicate high backscatter. 


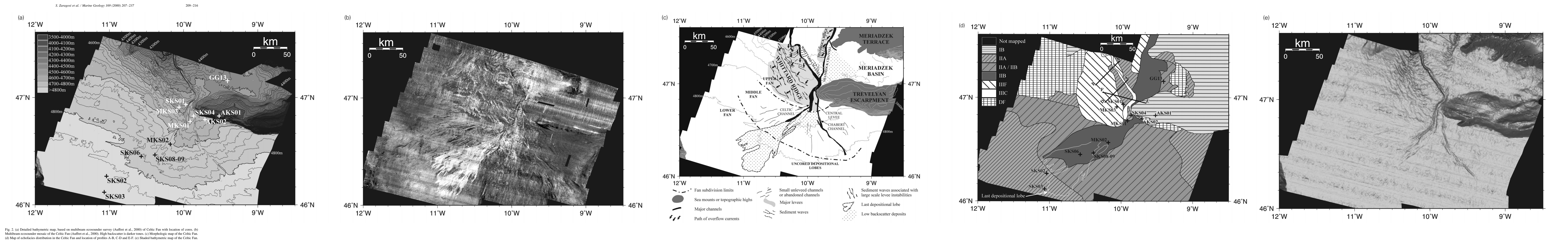


Table 1

Location of cores

\begin{tabular}{|c|c|c|c|c|c|c|}
\hline Core number & Latitude & Longitude & $\begin{array}{l}\text { Depth } \\
\text { (m) }\end{array}$ & Cruise & Year & Institute \\
\hline MD952002 & $47^{\circ} 27.12^{\prime} \mathrm{N}$ & $08^{\circ} 32.03^{\prime} \mathrm{W}$ & 2174 & MD IMAGE 1 & 1995 & IFREMER \\
\hline MKS01 & $46^{\circ} 46.53^{\prime} \mathrm{N}$ & $09^{\circ} 54.53^{\prime} \mathrm{W}$ & 4580 & MODENAM & 1996 & IFREMER \\
\hline MKS02 & $46^{\circ} 33.79^{\prime} \mathrm{N}$ & $10^{\circ} 10.63^{\prime} \mathrm{W}$ & 4670 & MODENAM & 1996 & IFREMER \\
\hline MKS03 & $46^{\circ} 54.63^{\prime} \mathrm{N}$ & $10^{\circ} 03.60^{\prime} \mathrm{W}$ & 4540 & MODENAM & 1996 & IFREMER \\
\hline AKS01 & $46^{\circ} 49.73^{\prime} \mathrm{N}$ & $09^{\circ} 30.98^{\prime} \mathrm{W}$ & 4030 & ACORES & 1996 & SHOM \\
\hline $\mathrm{AKSO} 2$ & $46^{\circ} 47.62^{\prime} \mathrm{N}$ & $09^{\circ} 42.33^{\prime} \mathrm{W}$ & 4595 & ACORES & 1996 & SHOM \\
\hline SKS01 & $46^{\circ} 56.10^{\prime} \mathrm{N}$ & $09^{\circ} 57.99^{\prime} \mathrm{W}$ & 4540 & SEDIFAN & 1997 & IFREMER \\
\hline SKSO2 & $46^{\circ} 15.95^{\prime} \mathrm{N}$ & $11^{\circ} 02.11^{\prime} \mathrm{W}$ & 4818 & SEDIFAN & 1997 & IFREMER \\
\hline SKS03 & $46^{\circ} 07.05^{\prime} \mathrm{N}$ & $11^{\circ} 04.00^{\prime} \mathrm{W}$ & 4824 & SEDIFAN & 1997 & IFREMER \\
\hline SKS04 & $46^{\circ} 49.60^{\prime} \mathrm{N}$ & $09^{\circ} 51.60^{\prime} \mathrm{W}$ & 4601 & SEDIFAN & 1997 & IFREMER \\
\hline SKS06 & $46^{\circ} 26.94^{\prime} \mathrm{N}$ & $10^{\circ} 33.99^{\prime} \mathrm{W}$ & 4783 & SEDIFAN & 1997 & IFREMER \\
\hline SKS08 & $46^{\circ} 27.75^{\prime} \mathrm{N}$ & $10^{\circ} 22.85^{\prime} \mathrm{W}$ & 4760 & SEDIFAN & 1997 & IFREMER \\
\hline SKS09 & $46^{\circ} 27.78^{\prime} \mathrm{N}$ & $10^{\circ} 22.94^{\prime} \mathrm{W}$ & 4756 & SEDIFAN & 1997 & IFREMER \\
\hline GG 72113 & $47^{\circ} 08.90^{\prime} \mathrm{N}$ & $09^{\circ} 24.40^{\prime} \mathrm{W}$ & 4396 & GEOGAS & 1972 & IGBA \\
\hline
\end{tabular}

$6000 \mathrm{~km}$ of hull-mounted $3.5 \mathrm{kHz}$ seismic lines were collected during the IFREMER cruises (MODENAM and SEDIFAN 1) and SHOM cruises. In addition $900 \mathrm{~km}$ of $3.5 \mathrm{kHz}$ seismic lines were collected during the cruise SEDIFAN 2 with the SAR high-resolution deep-towed sidescan system.

\subsection{Sedimentary cores}

Twelve Küllenberg cores were collected during the cruises ACORES (SHOM, 1996), MODENAM (IFREMER, 1996), and SEDIFAN (IFREMER, 1997) (Table 1, Fig. 2a). After physical properties measurements (magnetic susceptibility and gamma density), thin slabs (15 mm thick) were sampled and analysed in the SCOPIX X-ray image processing tool (Migeon et al., 1999). Subsamples were taken in order to measure: (1) carbonate content using gasometric calcimetry; and (2) the grain size using a Coulter LS 130 and a Malvern MASTERSIZER S.

\subsection{Stratigraphy}

Usual piston cores about $10 \mathrm{~m}$ long penetrate only the superficial part of thick sedimentary deposits typical of submarine fans and thus sample only the most recent time intervals. For this reason, our study of the fan deposit evolution is limited to the last 24,000 BP.

The stratigraphic framework is based on planktonic foraminifer investigations, $\delta^{18} \mathrm{O}$ isotopic analyses and AMS ${ }^{14} \mathrm{C}$ dating. The IMAGES core MD952002 located on the Meriadzek Terrace was used as a referential record for the Bay of Biscay (Table 1, Fig. 3) and was compared to previous results in the area (Pujol, 1980; Duplessy et al., 1981; Loncaric et al., 1998). The Marine Isotope Stages and estimated ages are derived from $\delta^{18} \mathrm{O}$ isotopic chronology (Martinson et al., 1987) and from ${ }^{14} \mathrm{C}$ dating.

The limit between the Marine Isotopic Stage 2 (MIS 2) and the MIS 1 is located at 12,050 BP (Martinson et al., 1987). This limit is characterised by the shift from arctic/subarctic microfauna to transitional/subtropical winter microfauna (Fig. 3, Table 2).

The limit between the MIS 3 and MIS 2 is estimated at $24,000 \mathrm{BP}$. In the Bay of Biscay, this limit is characterised by a change from transitional to subarctic microfauna.

During the MIS 1 (postglacial phase), a sporadic development of a left-coiling population of Globorotalia truncatulinoides occurs. The peak of abundance is dated at $9078 \mathrm{BP}$ in the core MD952002 (Fig. 3). This event is recognised throughout the entire North Atlantic and begins at $9800 \mathrm{BP}$ and finishes at $7000 \mathrm{BP}$ (Pujol, 1980; Auffret et al., 1996). It is associated with a change in the coiling ratio of the Globorotalia hirsuta population (Fig. 3). At the base of the postglacial phase (Bølling-Allerød event), the G. hirsuta 

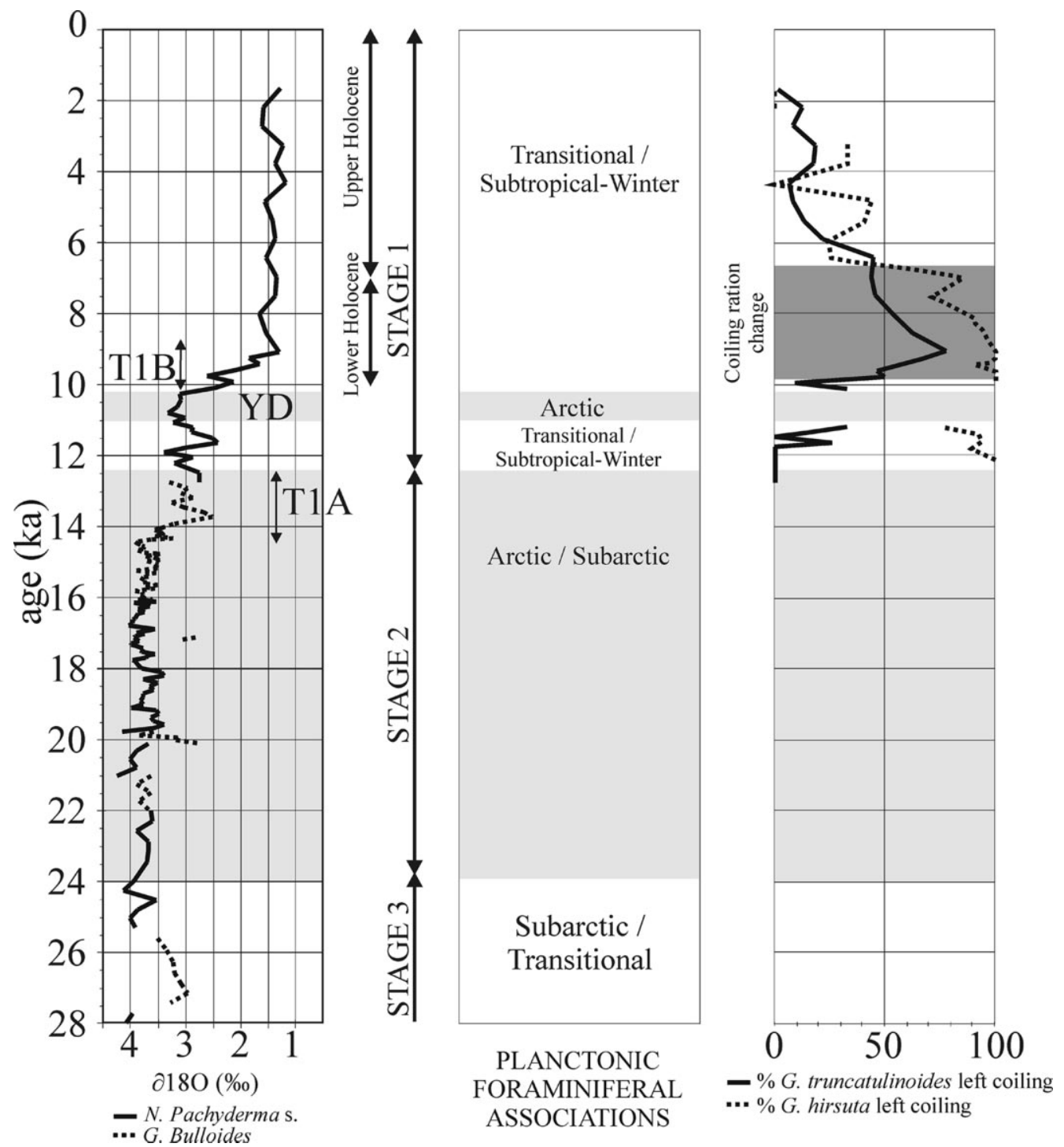

Fig. 3. Reference stratigraphic framework using the core MD952002 located on Meriadzek Terrace.

population is mostly sinistral. They will become dextral, as they are today, synchronous to the decrease of the left-coiling population of $G$. truncatulinoides.

These changes in coiling ratio allow separation of the MIS 1 period into: (1) the upper Holocene $(0-$ $7000 \mathrm{BP})$; (2) the lower Holocene (7-10,000 BP); and (3) the Bølling-Allerød event (10-12,000 BP).

AMS ${ }^{14} \mathrm{C}$ dating was performed on planktonic foraminifers by the Beta Analytic Radiocarbon Dating Laboratory (Cores SKSO2 and SKS04) and by the Laboratory of AMS dating at Gif-sur-Yvette (Core MKS03 and MD952002) (Table 3). All ${ }^{14} \mathrm{C}$ dates are corrected for the reservoir effect of -400 years. Calibrations to calendar ages are proposed in Table 3 using the Stuiver calibration (Stuiver et al., 1998).

$\delta^{18} \mathrm{O}$ isotopic analyses on planktonic foraminifers have been made at the Laboratory of Environmental and Climate Sciences (LSCE) at Gif-sur-Yvette (Core MKS03 and MD952002). 
Table 2

Planktonic foraminiferal association

\begin{tabular}{lll}
\hline Arctic & Subarctic & Transitional/subtropical \\
\hline Neogloboquadrina pachyderma Left coiling & Neogloboquadrina pachyderma Right coiling & Orbulina universa \\
& Globigerina bulloides & Globorotalia truncatulinoides \\
& Globigerina quinqueloba & Globorotalia hirsuta \\
& & Globorotalia inflata \\
& & Turborotalia humilis \\
& & Globigerinita glutinata \\
& Globorotalia scitula
\end{tabular}

\section{Results}

\subsection{Fan morphology}

According to morphological and acoustical characteristics, the Celtic Fan is divided into three main physiographic areas: the upper, middle and lower fan (Fig. 2c).

The upper fan extends from the $4200 \mathrm{~m}$ isobath to $4650 \mathrm{~m}$ depth, beyond which lobes begin to develop. It is characterised by two main tributary channels: (1) the Whittard Channel, to the west, which is a prominent sinuous tributary channel, directly connected to the Whittard Canyon; and (2) the Shamrock Channel to the east, with a smoother surface expression, which is the prolongation of the Shamrock Canyon.

The Whittard Channel (Figs. 2 and 4) is $2.5-3 \mathrm{~km}$ wide, approximately $100 \mathrm{~km}$ long, and has $70-150 \mathrm{~m}$ of relief from the channel floor to the right levee crest. The bordering levees are strongly asymmetrical. The right levee is $60 \mathrm{~km}$ wide, while the left one is less

Table 3

AMS ${ }^{14} \mathrm{C}$ ages with calendar age correspondences (Stuiver et al., 1998)

\begin{tabular}{lrrr}
\hline Core number & \multicolumn{1}{l}{$\begin{array}{l}\text { Sample } \\
(\mathrm{cm})\end{array}$} & $\begin{array}{l}\text { Conventional } \\
\text { age (reservoir } \\
\text { correction) (BP) }\end{array}$ & $\begin{array}{l}\text { Calendar age } \\
\text { (Cal BP) }\end{array}$ \\
\hline SKS04 & $28-31$ & $1218 \pm 40$ & 1177 \\
SKS02 & $56-58$ & $1879 \pm 40$ & 1880 \\
SKS02 & $91-93$ & $11,120 \pm 50$ & 13,007 \\
MKS03 & $0-1$ & $1268 \pm 60$ & 1237 \\
MKS03 & $29-30$ & $7028 \pm 80$ & 7902 \\
MKS03 & $306-307$ & $12,758 \pm 110$ & 15,302 \\
MKS03 & $360-361$ & $12,648 \pm 100$ & 15,168 \\
MKS03 & $492-493$ & $12,718 \pm 120$ & 15,257 \\
\hline
\end{tabular}

than $10 \mathrm{~km}$ wide. The right levee is named the Whittard Ridge. This ridge spreads over an area of about $3500 \mathrm{~km}^{2}$ and is covered by a field of sediment waves. (Figs. 2 and 4). Sediment waves are particularly conspicuous along the sinuous section of the channel. Their wavelengths range from 500 to $2000 \mathrm{~m}$ and their amplitudes from 5 to $50 \mathrm{~m}$. On the levee back-slope sediment waves are associated with rotational faults and slumps due to levee instabilities (Figs. 2c and 4).

Presently, the Shamrock Channel, $(2200 \mathrm{~m}$ wide and $10-50 \mathrm{~m}$ deep) associated with the Shamrock Ridge is partly filled (Fig. 2c and e). This channel transports sediment downstream from the Little Sole Drainage Area to: (1) the Meriadzek Basin, a small marginal basin of $2500 \mathrm{~km}^{2}$ located between the Meriadzek Terrace and the Trevelyan Escarpment; and/or (2) to the middle and lower Celtic Fan. The Shamrock Ridge is the single levee of the Shamrock Channel. This ridge is of small size $\left(500 \mathrm{~km}^{2}\right)$ and is also covered by a field of sediment waves perpendicular to the channel axis.

To the South, the Whittard Channel and the Shamrock Channel merge into a unique main channel in the narrow passage induced by the Trevelyan Escarpment and the Whittard Ridge (Fig. 2c). This passage constitutes an area where all the supplies, coming from the Great Sole and Little Sole drainage areas, mix together before their transfer into the distributary channels and the middle and lower fan. At present, the deep distributary channel system radiates outward from this sediment distribution point, with two main active distributary channels: (1) the Celtic Channel to the west associated with the southernmost part of the Whittard Ridge; (2) the Chabert Channel to the east. A low relief levee called the "Central Levee" 
is located between these channels (Fig. 2c). Each of these channels feeds a complex network of secondary braided channels.

The upper-middle fan boundary corresponds to the disappearance of the channel-levee systems and the appearance of lobe deposits. The middle-lower fan boundary is approximately marked by the downslope disappearance of the secondary channels at the scale of the multi-beam bathymetric maps. The middle and lower fan include the area of secondary channels and their related lobes. It is smooth and very gently sloping with an average gradient of $0.05^{\circ}$. Numerous small unleveed secondary channels cross this part of the fan. A specific morphological unit with a very low backscatter corresponds to a depositional lobe (Fig. 2). This low-backscattering lobe is built downstream of the Celtic Channel by imbricated braided secondary channels and finger-like sublobes. It is superimposed on higher-backscatter structures (older lobes) and its lateral boundaries cut across the bedforms covering these older lobes. The low-backscattering lobe is the latest depositional lobe. It has an approximate length of $90 \mathrm{~km}$ and a width of $45 \mathrm{~km}$ and has a surface area of about $3200 \mathrm{~km}^{2}$

\subsection{Sediment distribution}

\subsubsection{Sedimentary facies}

Seven sedimentary facies types have been recognised in twelve cores from the Celtic Fan. These facies types have been defined using: (1) photography and X-ray imagery; (2) grain size analyses and $\mathrm{CaCO}_{3}$ content; and (3) comparison with previous sedimentary facies classifications (Pickering et al., 1986; Normark and Damuth, 1997).

Most of the cores display few coring artefacts and no disruption due to gas expansion.

\subsubsection{Facies 1: homogenous, structureless marly} ooze: pelagic to hemipelagic marly ooze. Facies 1, with relatively high concentration of foraminifera, is composed of structureless light grey to light brownish grey marly ooze. The mean grain size is less than $10 \mu \mathrm{m}$ and the $\mathrm{CaCO}_{3}$ content ranges between 30 and $60 \%$.

This facies forming the modern seafloor has been interpreted as pelagic to hemipelagic drape deposits.

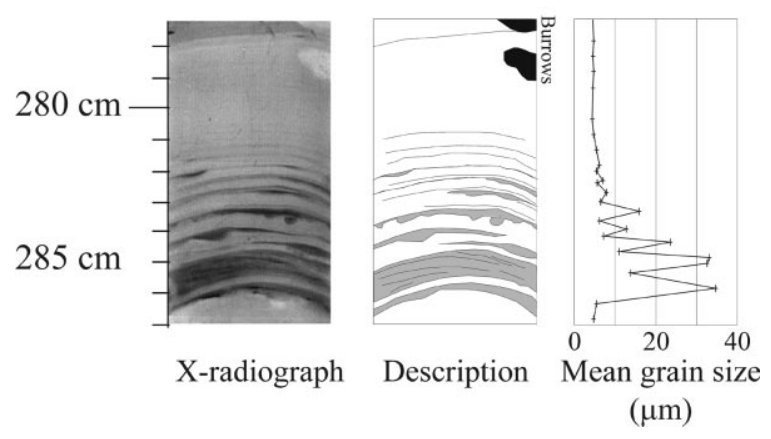

Fig. 5. Example of Facies 3 (section of core SKS01) consisting of alternating silt and mud laminae, with an upward decrease in the thickness of individual silt laminae. This facies is interpreted as fine-grained turbidites.

It is observed in the majority of the Celtic Fan cores within the MIS 1 interval.

3.2.1.2. Facies 2: homogenous, structureless clay: hemipelagic clays. Facies 2 consists of thin (few centimetres) to thick (several metres) intervals of structureless olive grey clay. The mean grain size is less than $10 \mu \mathrm{m}$ and the $\mathrm{CaCO}_{3}$ content less than $20 \%$.

This facies is present during the MIS 2 and has been interpreted as hemipelagic drape deposits.

Facies 2 contains in places black coloured bands. This banding is present in several deep environment facies (Cremer, 1982; Nelson et al., 1992; Normark and Damuth, 1997) and is usually due to the presence of black hydrotroilite. Selective hydrotroilite staining causes laminations. This facies suggests organic rich supplies and/or enhanced preservation. This preservation is due to high sedimentation rates and/or anoxic bottom water conditions (Stow et al., 1996).

\subsubsection{Facies 3: laminated silt and clay: fine-grained} turbidites. Facies 3 consists of thinning up silt laminae (Fig. 5). It forms sequences with sharp contacts at both base and top, and shows important variations in thickness $(1$ to $20 \mathrm{~cm})$. The number of silt laminae varies from 1 to 15 , sometimes the basal laminae shows cross-stratifications. The mean grain size varies from $50 \mu \mathrm{m}$ (silt laminae) to $5 \mu \mathrm{m}$ (clay intervals). The $\mathrm{CaCO}_{3}$ content is less than $30 \%$. These sequences are observed during both the MIS 1 and 2. During the MIS 2 this facies could contain black hydrotroilite colour bands. 
This fine-grained turbidite facies ( $\mathrm{Td}$ and $\mathrm{Te}$ divisions of the Bouma turbidite sequence; Bouma, 1962) is interpreted as being deposited by low-density turbidity currents.

3.2.1.4. Facies 4: thin bedded very fine sands: finegrained turbidites. Facies 4 varies from very fine sand to coarse silt and forms layers with a thickness lower than $5 \mathrm{~cm}$. It commonly exhibits apparent flow-in caused by the coring. The layers without disruption show contact at bottom, cross-stratifications and grade upward from very fine sands to silts. They are observed during both the MIS 1 and 2, systematically associated to the Facies 3. They were interpreted as fine-grained turbidites (Tc division of Bouma).

\subsubsection{Facies 5: thick, disorganised sandy layers:} turbidite and/or non-cohesive debris flow deposits (grain flow). Facies 5 consists of fine sand beds with a thickness up to $50 \mathrm{~cm}$. These layers appear to be massive or structureless with large, irregularly shaped mud clasts.

These sandy layers, mainly composed of detritus (quartz), are only observed during the MIS 1. They are interpreted as being deposited by high-density turbidity currents (Ta division of Bouma) and/or non-cohesive debris flows.

3.2.1.6. Facies 6: thick, organised sands: turbidite. Facies 6 consists of medium to very fine sand, with a layer thickness up to $10 \mathrm{~cm}$. They display a variety of bedding structures: (1) normally graded; (2) inversely graded; and (3) ungraded but with a normally graded terrigenous part after carbonate removal.

The composition varies from terrigenous (quartz) to biogenic (forams). These graded sandy layers are only observed during the MIS 1. They are interpreted as being deposited by high-density turbidity currents (Ta division of Bouma).

3.2.1.7. Facies 7: disorganised sandy clays: slump or debris flow. Facies 7 consists of thick intervals $(>1 \mathrm{~m})$ of deformed or chaotic clay with mud clasts, or discordant, contorted, folded beds (Fig. 6). It can contain deformed silty to sandy layers. Several of theses facies contain black hydrotroilite colour bands, which emphasize the disruption. This facies is interpreted as resulting from mass transport deposits (slump or debris flow).

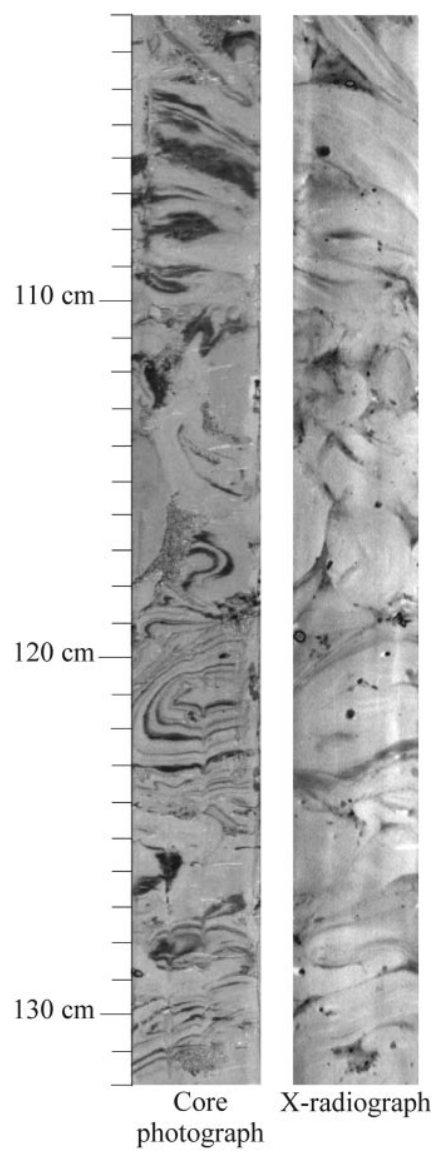

Fig. 6. Example of Facies 7 (section of core SKS08) consisting of deformed or chaotic clay with silty to sandy layers. This example contains black hydrotroilite colour bands, which emphasise the disruption on the core photograph. This facies is interpreted as resulting from mass transport process (slump or debris flow).

\subsubsection{Seismic $3.5 \mathrm{kHz}$ echofacies}

In this study the $3.5 \mathrm{kHz}$ echofacies have been classified according to Damuth's methodology (Damuth, 1975; Damuth and Hayes, 1977; Damuth, 1980). The echo-character mapping and the interpretation are carried out using, in addition, the multibeam echosounder data (bathymetry and imagery) and the core lithologies.

Seven types of echofacies have been recognised on the hull-mounted profiles from the study area (Table 4). The map of echofacies distribution (Fig. 2d) is a compilation of the $3.5 \mathrm{kHz}$ data available on the fan. 
Table 4

$3.5 \mathrm{kHz}$ echofacies classification using the Damuth echo types (Damuth and Hayes, 1977; Damuth, 1980)

\begin{tabular}{lll}
\hline Echo type & Interpretation & Details
\end{tabular}

IB

Sharp continuous with numerous parallel sub-bottoms
Hemipelagic sedimentation

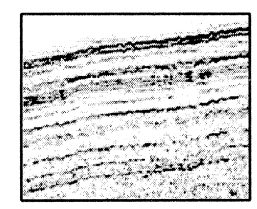

Intermediate between $I I A$ and $I I B$

IIIC

Regular overlapping hyperbolae with varying vertex elevations

Irregular and/or steep sea-floor (channel)

Sediment waves and/or levee instabilities

Irregular single hyperbolae with nonconformable sub-bottoms

\section{DF}

Acoustically transparent unit with prolonged echoes or regular overlapping hyperbolae tangent to the sea floor
1. Occurrence of coarse sediment

2. Hemipelagic sedimentation with interbeds of coarse sediment

3. Sequences of alternating silt and clay laminaes

Occurrence of thick, coarse, bedded sediment

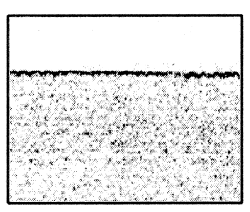

Intermediate between $I I A$ and $I I B$
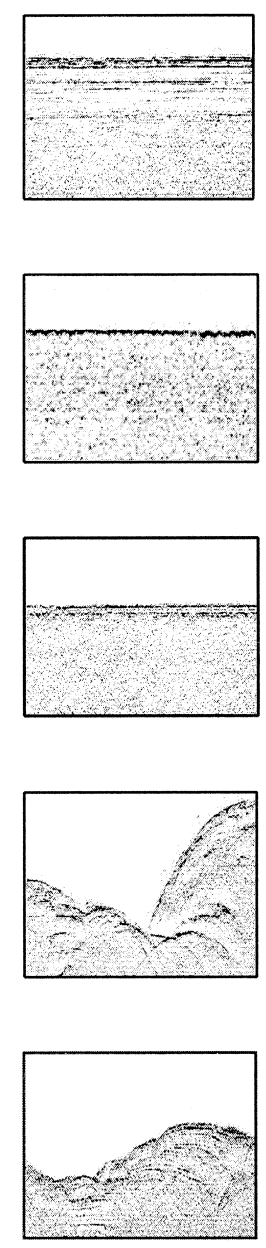

Mass-transport deposits as slumps or debris flows

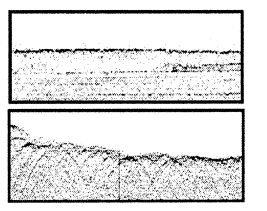




\subsubsection{Sediment distribution on the upper fan}

The $3.5 \mathrm{kHz}$ echofacies of the Shamrock Ridge essentially consists of echo-type IIIF. This echo is associated with the presence of sediment waves (Fig. 2c-e). Despite the lack of sampling, the occurrence of overbank deposits on the ridge can be related by the following attributes: (1) the localisation of the ridge along the Shamrock Channel; (2) the presence of sediment waves; and (3) the orientation of the sediment wave crest which is perpendicular to the assumed path of overflow currents (Fig. 2c and d).

The presence of the IIB echo (very-prolonged without sub-bottom reflectors) on the floor of the Shamrock Channel indicates the presence of coarse sediments. The gentle relief of this channel and the absence of hyperbolic echoes indicate that this channel is partly filled by the last gravity events.

On the Meriadzek Basin, the $3.5 \mathrm{kHz}$ echofacies presents an evolution from the Shamrock Channel to the eastern deeper part of the basin. This organisation from the IIB echofacies to the west to IIA-IIB and IIA eastward suggest a decrease in the grain size and thickness of coarse grained deposits. The Geogas 72113 core (GG13) located in the middle of the basin in the IIA/IIB echofacies area (Fig. 2a) is composed of homogeneous fine sand (Berthois et al., 1973) and confirms the occurrence of sandy deposits. The $I I B$ echofacies area is composed of a southward elongated tongue along the Shamrock Channel in addition to the lobe-shaped area in the Meriadzek Basin. All this data suggests that part of the sand coming from the Shamrock Channel, which is fed by the Little Sole drainage area, is deposited on the Meriadzek Basin and the other part is transported further down the Channel and merges southward with the Whittard Channel sediments.

The presence of $D F$ echofacies in the eastern part of the Meriadzek Basin could be related to local slumps or debris flows coming from the slopes of the Meriadzek Terrace or the Trevelyan Escarpment.

On the Whittard Ridge, two echo type areas are present (Fig. 2d). The IIA echo type area located along the straight path of the Whittard Channel corresponds to semi-prolonged echoes with intermittent sub-bottoms. The IIIF echo-type area located northward of the Whittard Ridge, on its outward surface, is constituted of semi-prolonged echoes with irregular hyperbolaes. This echofacies is asso- ciated with the presence of both sediment waves and levee instabilities (rotational faults and slumps) (Figs. 2d and 4).

Two cores have been collected on the Whittard Ridge and are localised in the south of the Ridge (SKS01 in IIA echofacies area and MKS03 in IIIF echofacies area, Figs. 2a and 7). The cores mainly consist of two sedimentary facies: (1) laminated silt and clay (Facies 3 ) is the most common facies $(90 \%$ of the cores) associated with; and (2) a few beds of coarser sediment (Facies 4). The IIA and IIIF echofacies associated with turbidite deposits (Facies 3 and 4) reflect the building of the Whittard Ridge by turbidite overflow processes. However, the occurrence of sediment waves and deposits disturbed by rotational faults, slumps and erosive features result in the IIIF hyperbolic echotype. The disturbances are due to: (1) gravity destabilisation induced by the levee growth and sedimentary stacking; and (2) gravity currents coming from the King Arthur Canyon to the North. These currents are responsible for erosion on the levee sea-floor and discontinuities on the $3.5 \mathrm{kHz}$ records. The $D F$ echofacies in the northwestern part of the studied area is related to another system supplied by the King Arthur Canyon (Figs. 1 and 2d).

In the narrow passage induced by the Trevelyan Escarpment and the Whittard Ridge, the two distributary channel floors (Celtic and Chabert channels, Fig. 2c) present a downslope evolution from the hyperbolic IIIF to the low penetration IIB echofacies. This evolution reflects the modification of the channel morphology with a valley relief decreasing just before the uppermiddle fan limit. No core was directly collected from the axis of these channels. The two available cores, SKS04 and MKS01 (Fig. 2a), are located on the edges of the Central Levee, between the Celtic and Chabert channels. The SKS04 core near the Chabert Channel consists of graded sandy layer (Facies 6) overlying homogenous marly oozes (Facies 1) and thin sand layers. The MKS01 core located in the south of the Central Levee near the Celtic Channel consists of a very thick $(150 \mathrm{~cm})$ disorganised sandy layer (Facies 5) overlying silt and clay laminae sequences (Facies 3). Despite the absence of cores from the bottom of the channels, the sandy nature of channel-fill deposits can be expected from: (1) the presence of sandy layers on the edge of the channels (SKS04 and MKS01, Fig. 


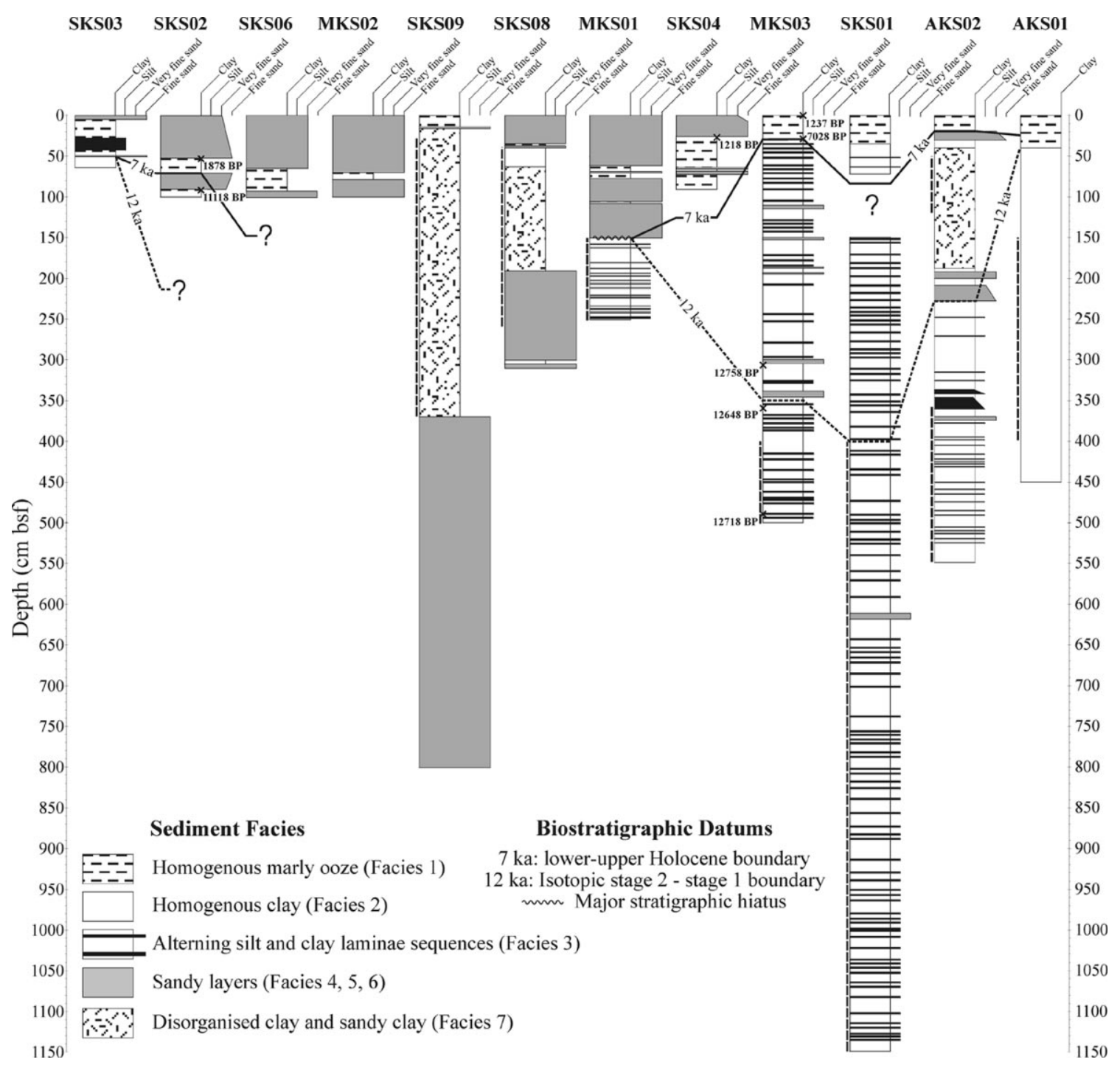

Fig. 7. Sedimentological core logs from the Celtic Fan, showing grain-size variation, lithology and bed thickness. Dashed lines on the left side of logs show the presence of black hydrotroilite staining (location of cores are presented in Fig. 2a and d).

7); (2) the low backscatter at the bottom of the channels (Fig. 2b); and (3) the nature of the $3.5 \mathrm{kHz}$ echofacies (IIIF and IIB; Table 4, Fig. 2d).

The $D F$ echofacies (Table 4, Fig. 2d) located at the foot of the southern part of the Trevelyan Escarpment indicates the probable presence of large slumped layers. This is confirmed by evidence of sediment failures observed in the core AKS02 collected at this location (Fig. 2a). This core has disorganised clays (Facies 7) interbedded, in the interval between 40 and $150 \mathrm{~cm}$, with deposits showing the same facies organisation as the Whittard Ridge cores. This mass transport deposit indicates the occurrence of episodic sediment failures on the Trevelyan Escarpment slope.

\subsubsection{Sediment distribution on the middle and lower fan}

The $3.5 \mathrm{kHz}$ echofacies distribution shows (Fig. 2d): (a) a downslope evolution (from $I I B$ to 
IIA/IIB and then to IA) which suggests a thinning of the sandy layer and is linked to the trend of the supply transports; and (b) a lateral evolution, perpendicular to the supply trend, which is marked by a symmetrical organisation of the echofacies with respect to $I I B$ echofacies area. This $I I B$ area, located slightly northward of the low-backscatter lobe (Fig. 2d), constitutes the most recent preferential sand deposit area. The low-backscatter lobe shifted to the south represents only the latest gravity events.

Six cores collected from this part of the fan are located on the low-backscatter lobe (Fig. 2). The cores MKS02, SKS06, SKS02 and SKS03 have been collected on a NE-SW transect from the mouth of the Whittard Channel to the distal end of this depositional lobe. These cores are composed of sandy layers (Facies 5 and 6) interbedded in the hemipelagic deposits (Facies 1). It is impossible to correlate the different sandy layers using the existing data. The elongated shape of the low-backscatter lobe, and the graded nature of the sedimentary units (Facies 6) indicate that highly efficient turbidity flows have transported coarse-grained sediments from the channel mouth across the lower fan.

The cores SKS08 and SKS09, located on a gentle levee inside the lobe, display disorganised clay and sandy clay (Facies 7, Fig. 6). From the existing data, it is impossible to discern if these deposits are the result of local sediment failures or of large-scale masstransports from the upper part of the fan.

\section{Discussion}

\subsection{Fan model}

The sedimentary processes involved in the construction of fan units (channels, levees and lobes), are now largely documented in the literature (for an overview see Stow et al., 1996). The term "channel" includes both the large leveed valley with a wide cross section and steep sides and the smaller commonly unleveed channels. The former are the primary sediment feeder systems. Their shape is controlled by erosional and transport processes. The others, with low surface expression, are controlled by transport and depositional processes. For the large leveed channels, the overflow processes contribute to the levee growth. The right-hand levees are higher and broader than the left-hand levees in the north hemisphere, this being controlled by the Coriolis force deflecting the turbidity currents to the right. The centrifugal force associated with flow stripping processes is responsible for the preferential building of sediment waves at the outer corners of bends of the levees (Piper and Normark, 1983). The upper-middle fan boundary is the result of the disappearance of the channel-levee systems due to the progressive downpath decrease of the fine-grained fraction in sediment transported by the channelised flows.

In the literature the term "lobe" is used to define very different submarine fan facies on many different scales (Shanmugam and Moiola, 1991). In the present study, the term "lobe" is restricted for very low-relief depositional bodies located on the middle and lower fan. They lie immediately downslope of main channels and have generally unleveed secondary channels on their inner part. The difficulty of coring and the very low penetration of the $3.5 \mathrm{kHz}$ seismic waves does not make the study of such environment easy. The transition from a muddy channel-levee system on the upper fan to flat-lying sand lobes on the middle and lower fan, represents a facies shift related to particle sorting and segregation due to channel-levee overflow as shown in the Amazon Fan (Flood and Piper, 1997), Mississippi Fan (Bouma, 1985), Navy Fan, (Piper and Normark, 1983).

In agreement with the classification of Reading and Richards (1994), which is based on the nature of the available sediment (volume and grain size) and on the nature of the supplying system, the whole Celtic Fan system corresponds to a mature, $\mathrm{mud} / \mathrm{sand}$-rich submarine fan. In more detail, the comparison of the Celtic system with other fans and models shows a more complex organisation. The Celtic Fan is characterised by the existence of two sedimentary sources on the upper fan. Just before the upslope boundary of the middle fan, the two channels merge into one channel corresponding to a single feeding "source" for the middle and lower fan. In this way, the Celtic Fan is a multiple source ramp on the upper fan and a single source fan for the middle and lower fan.

On the upper fan, the Shamrock system and the Whittard system have distinct patterns. These two 
systems drain different parts of the shelf, and are submitted to sedimentary sources that differ quantitatively as well as qualitatively.

The Whittard system has a large, persistent, sinuous channel-levee system. Studies of core lithology and morphology of the system show that relatively low-density turbidity currents are presumed for the majority of the supplies. The Whittard system seems to be more mature or to have undergone finer grained supplies than the Shamrock system because of its greater channel length and depth, its sinuous pattern and the important development of its levee.

Unlike the Whittard system, the Shamrock system has a lower relief expression. The last sandy gravity events seem to have partly filled the Shamrock Channel. This system allows the deposition of sand sheets as soon as the upper fan. Part of the supplies merges with the Whittard system just before the middle fan.

On the middle and lower fan, individual small-sized lobes without important surface expression, are generated following periodic avulsions of middle fan channels. They correspond to the spreading of individual sheet-flows. The passage to the basin plain is progressive with the downward thinning of the turbidite layers.

\subsection{Sedimentary processes evolution}

To determine the evolution of sedimentary supplies to the Celtic Fan, the core MKS03 (Fig. 2a) was sampled for sedimentological, palaeontological and geochemical analyses (Fig. 8). This core is located on the south of the Whittard Ridge downstream of the Whittard and Shamrock Channels reunion. To determine the sedimentological background in the vicinity of the study area, the core AKS01 located on the Trevelyan Escarpment (Fig. 2a) was analysed. This core, collected very close to the fan $(12 \mathrm{~km})$, is protected from sandy-silty turbidite supplies and presents an undisturbed evolution from homogenous clay (Facies 2) during the MIS2 to homogenous marly ooze (Facies 1) during the entire MIS1 (Fig. 7).

On the Whittard Ridge the analyses of the core MKS03 $\left(\delta^{18} \mathrm{O},{ }^{14} \mathrm{C}\right.$ AMS dating, $\mathrm{CaCO}_{3}$ content and forams determination) provides information about the evolution of the supplies since the last glaciation (Figs. 2a, 7 and 8). Three phases are depicted throughout the records. Phase 1 corresponds to the end of the MIS 2 with higher $\delta^{18} \mathrm{O}$ values and lower $\mathrm{CaCO}_{3}$ contents. During this phase overflow processes occur on the Whittard Ridge as shown by the presence of laminated silt and clay (Facies 3). Phase 2 corresponds to the beginning of the MIS 1 (Bølling-Allerød, Younger Dryas and lower Holocene). During this phase, overflow processes remain active on the Whittard Ridge where Facies 3 and 4 are deposited. The $\mathrm{CaCO}_{3}$ and $\delta^{18} \mathrm{O}$ values of the Phase 2 are intermediate between Phase 1 and Phase 3 . This signal is due to the mixing of sediment from MIS 2 and MIS 1 transported by the turbidite processes. Phase 3 corresponds to the upper Holocene with low $\delta^{18} \mathrm{O}$ values and high $\mathrm{CaCO}_{3}$ contents. This period is characterised by the cessation of overflow processes and the occurrence of hemipelagic sedimentation (Facies 1). The increase of the $\mathrm{CaCO}_{3}$ contents is related to the decrease of the sedimentation rates due to the absence of turbidite supplies on the ridge (from $85 \mathrm{~cm} / \mathrm{ka}$ for the phase 2 to $5 \mathrm{~cm} / \mathrm{ka}$ for the phase 3) rather than an increase in surface biological production.

Considering its geographic localisation (south of the Whittard Ridge), the MKS03 core would have recorded both the supplies from the Whittard system and from the Shamrock system. In the upper Holocene (since $7000 \mathrm{BP}$ ) the interruption of the overflow processes on the site of the core MKS03 points to a cessation of the turbidity currents or a change in their nature.

The short length of the cores coming from the middle and lower fan (Fig. 7) does not allow reconstruction of the supply history since the last glaciation. Nevertheless, biostratigraphic investigations and ${ }^{14} \mathrm{C}$ dating indicate that the sandy layers present in the cores from the uppermost lobe were deposited during the MIS 1 and mainly during the upper Holocene (Fig. 7). Two AMS ${ }^{14} \mathrm{C}$ dates show that the latest sandy events in cores SKS02 and SKS04 are very recent, respectively, 1878 and $1218 \mathrm{BP}$ (Table 3).

The cores SKS03 and SKSO2 located on the lower fan, on the outer part of the uppermost lobe (Fig. 2 and 7), allow evaluation of the frequency of turbidite events during the Stage 1 in the area: 0.25 events/ka for SKS03 and 0.18 events/ka for SKS02. 


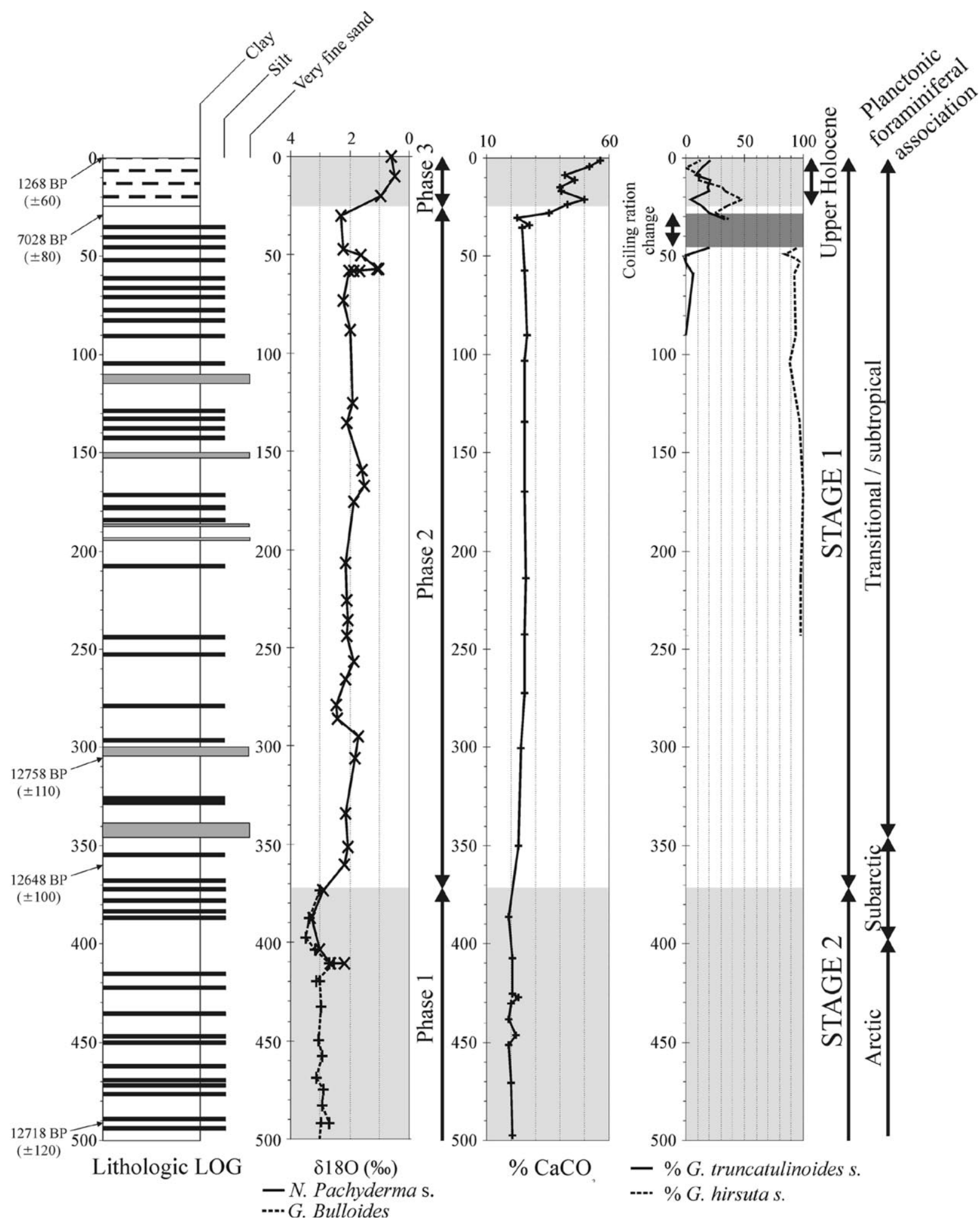

Fig. 8. Details of core MKS03 analyses showing AMS ${ }^{14} \mathrm{C}$ ages, $\delta^{18} \mathrm{O}$ record, $\mathrm{CaCO}_{3}$ contents and abundance $(\%)$ of the foraminifera $G$. truncatulinoides s. and G. hirsuta s. 
4.3. Palaeoceanographic control on the development of the fan

The development of the fan begins during the Miocene (Droz et al., 1999). In this study, the available cores allow the reconstruction of the fan history during the MIS 1 and 2 (0-24,000 BP). During this period, the Celtic Fan does not appear to have been built with a gradual and constant rate. There are distinct episodes of growth, with various sets of depositional processes.

From the MIS 2 to the upper-lower Holocene boundary $(7000 \mathrm{BP})$, the overbank deposits give evidence of regular turbidite supplies. During this period, a broad delta was developed on the shelf at the outflow of the Channel River (see Section 1.2). In this configuration a wide spectrum of material was available to be transported to the deep sea. These conditions are comparable to those of passive margin fans located downstream of large rivers such as the Amazon or the Mississippi.

At the end of MIS 2 and during the deglaciation (12-7000 BP), turbidite supplies continue to be deposited. This period corresponds to the rapid deglaciation phase when meltwater discharge and subsequent sediment load were perhaps several times higher than during the maximum lowstand when the British Isles was partly glaciated (McCabe and Clark, 1998). This configuration is similar to that of the Mississippi Fan just before the Younger Dryas (Broecker et al., 1989; Fairbanks, 1989; Twichell et al., 1991). Associated with the meltwater discharge, the reworking of the deltaic environment deposits induced by the sea-level rise (Belderson et al., 1986; Lericolais, 1997), would have allowed significant supplies to the deep sea.

Thus, the turbidite overflow deposits located on the Whittard Ridge contain particles originating from: (1) the north European palaeo-rivers during the MIS 2; (2) the erosion of the Channel River Delta during the sea-level rise; and (3) the meltwater discharges during the European deglaciation. The upper Holocene (0-7000 BP), marked by the end of turbidite overflow deposits on the Whittard Ridge, implies the disappearance of the active deltaic environments on the shelf, and the setting of the present hydrodynamic conditions.

The distribution of deposits, with channel-levee systems on the upper fan and sand lobes on the middle-lower fan, represents the classical downslope facies shift in a mud rich and mud/sand rich submarine fan (Piper and Normark, 1983; Bouma, 1985; Kolla and Coumes, 1987; Normark and Damuth, 1997). On the other hand, the sandy deposit on the uppermost lobe, during the last $2000 \mathrm{BP}$, has to be explained because the overflow processes in the channel-levee systems were inactive during the upper Holocene. Thus an important part of the supplies may have bypassed the channel-levee sector to reach downstream. The precise sources of these sands have not yet been identified. However, observations on benthic foraminifers from marly ooze clasts deposited with the sands (Cores MKS01 and MKS02; Fig. 7) show the presence of shelf and slope Pleistocene species (F. Jorinsen pers. com.). Gravity processes, which eroded these marly oozes, may have been triggered on the slope break or the upper slope. From the bathymetric and $3.5 \mathrm{kHz}$ seismic data (see Section 3.2.3), the Shamrock Channel appears to be filled up by the last turbidite events. Moreover, the low-backscatter nature of the EM12 signal around the Shamrock Channel, as for the low-backscatter lobe on the middle-lower fan (Fig. 2b), seems to point out a Shamrock Canyon transport for a part of sand deposits in the middle and lower fan. However this interpretation has to be confirmed by sampling on the bottom of the Shamrock and Whittard Channels. At the scale of the whole fan, these upper Holocene sands, modify only slightly the morphology that is mostly inherited from Pleistocene stages of high sedimentation rates.

How can we explain the occurrence of these sands? During the Holocene, the palaeoenvironmental conditions on the Celtic Shelf changed drastically (see Section 1.2). At present, it is a high-energy platform with a net sediment transport from the near shore to the margin slope (Kenyon and Stride, 1970; Johnson et al., 1982; Reynaud et al., 1999d). This transport involves storm and spring tide currents, destabilisation and mass flow induced by erosion of the Celtic Sea sand banks during paroxysmal events (storm, earthquake, ...) or induced by regressive canyon head erosion. This high sea-level working scenario of the Celtic Fan seems to be comparable to what happened in the Amazon Fan during the MIS 5. As on the Celtic Fan, the presence of sandy turbidite layers on the Amazon Fan during the MIS 5 (Flood 


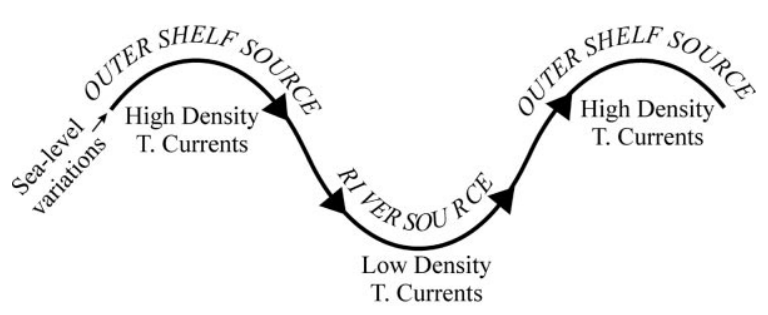

Fig. 9. Timing of Celtic Fan sedimentation with respect to sea-level fluctuations. The Celtic Fan sedimentation showing continuous turbidite sedimentation during the rise of sea-level (river source) and during the highstand of sea-level (outer shelf source).

and Piper, 1997) appears to be the result of outer shelf sand reworking.

Pliocene-Pleistocene eustatic cycles are classically interpreted as the major factors controlling the timing and style of sedimentation (Damuth, 1977; Shanmugam et al., 1985; Stow et al., 1985; Bouma et al., 1989; Weimer, 1990). At the lowest sea-level point, sediment derived from rivers and deltas are transported into the deep basin via submarine canyons and deposited as channel-levee systems and distal lobes. The low sea-level activity of the larger low latitude passive margin fans is dominant on several fans (e.g. Mississippi Fan (Bouma et al., 1989), Amazon Fan (Flood and Piper, 1997), Indus Fan (Kolla and Coumes, 1987)). For the majority of these fans, turbidite supplies ceased during the sealevel rise. During the highstand of sea-level, pelagic to hemipelagic drape sediments tend to be deposited on the fan surfaces.

The depositional model of the Celtic Fan shows some similarities with this general model of mud and mud/ sand rich systems. Nevertheless two distinct characteristics need to be noted: (1) the low sea-level supply scenario continues throughout all the rise of sea-level and ceased only in the upper Holocene (Fig. 9). The supplies are related to the meltwater discharge during the deglaciation phase and with the reworking and disappearance of the deltaic edifices; (2) the upper Holocene configuration with episodic turbidite supplies derived from reworked shelf sands (Fig. 9).

The majority of fans with turbidity current activity during highstands of sea-level are located downstream of narrow continental shelves and/or active margins: Hueneme Fan (Normark et al., 1998); Var Fan (Piper and Savoye, 1993); Zaire Fan (Droz et al., 1996); Toyama Fan (Nakajima et al., 1998); La Jolla Fan (Piper, 1970). The Celtic Margin configuration shows that on tide and wave-dominated shelves, hydrodynamic conditions on the outer shelf can create favourable conditions for modern sandy turbidite supplies on fans.

According to the sequence-stratigraphic models of Posamentier et al. (1991) turbidite deposits are considered to have the highest sand-to-mud ratio during lowstands. The depositional model of the Celtic Fan shows an opposite configuration with low-density turbidity currents during lowstand and rise of sea-level and high-density turbidity currents during highstand of sea-level (Fig. 9).

\section{Conclusions}

The Celtic Fan is a middle sized fan with a surface of more than $30,000 \mathrm{~km}^{2}$. The whole system is a mature, mud/sand rich submarine fan on a passive margin.

The upper fan is characterised by the presence of two distinct tributary systems: (1) The Whittard system with a large, persistent, sinuous channellevee system, which is linked to the southern end of the Irish Sea system. Relatively low-density turbidity currents are presumed for the majority of the flows moving down the Whittard Channels from analysis of the core lithology and the morphology of the system. (2) The Shamrock system, with a medium sized channel-levee system, which is linked to the western end of English Channel system. The last sandy gravity events seem to have partly filled this system. These two tributary systems merge before the upper-middle fan limit. The upper-middle fan boundary is the result of the disappearance of the channel-levee systems due to the downward progressive loss of the fine-grained material in the turbidity channelised flows. The middle and lower fans correspond to divergent braided secondary channels and associate lobes. Successive lobe elements, without important surface expression, are generated during periodic avulsions of middle fan channels.

The lithological, palaeontological, and geochemical analyses on twelve cores provide the evolution of the sedimentation since the last glaciation. The 
overflow deposits present on the Whittard Ridge during the Marine Isotope Stage 2 and during the beginning of the Marine Isotope Stage 1 (BøllingAllerød, Younger Dryas and lower Holocene) indicate the occurrence of relatively low-density turbidity currents initiated at the front of a deltaic environment on the outer-shelf (low sea-level period and sea-level rising phase). The very recent sandy layers $(<2000$ BP) located on the uppermost lobe on the middle-lower fan indicate episodic high-density turbidity currents and/or non-cohesive debris flow. This upper Holocene activity is derived from reworked outer shelf sands due to the high-energy conditions on the outer shelf during high sea-level periods.

\section{Acknowledgements}

The authors are grateful to the Service Hydrographique et Océanographique de la Marine (SHOM) and to the Institut Français de Recherche pour l'Expoitation de la Mer (IFREMER) for funding this study. We thank GENAVIR and the crew of the R/V Atalante, Suroit and Nadir for their technical assistance during the cruises Modenam and Sedifan. We are grateful to F. Vinçont, J. St Paul, D. Poirier, G. Chabaud, R. Kerbrat, R. Apprioual, G. Floch, J. Kervern, P. Guyomard and S. Lucas for technical assistance. Thanks are due to T. Mulder for valuable discussions and helpfull comments on the manuscript, and to V. Kapsimalis for his assistance with language. E. Le Drezen, M. Voisset, B. Loubrieu and S. Unterseh processed EM12 mosaics and bathymetric data. We also thank N.H. Kenyon, J.-Y. Reynaud and editor D.J.W. Piper for their constructive reviews and comments This study has been partially funded by the European Union Programme ENAM II (MAST 3). This is an U.M.R./ EPOC C.N.R.S. no. 5805 contribution no. 1342.

\section{References}

Auffret, G.A., Pujol, C., Baltzer, A., Bourillet, J.F., Müller, C., Tisot, J.P., 1996. Quaternary sedimentary regime on the Berthois Spur (Bay of Biscay). Geo-Mar. Lett. 16, 76-84.

Auffret, G.A., Zaragosi, S., Voisset, M., Droz, L., Loubrieu, B., Pelleau, P., Savoye, B., Bourillet, J.F., Baltzer, A., Bourquin, S., Dennielou, B., Coutelle, A., Weber, N., Floch, G., 2000.
Premières observations sur la morphologie et les processus sédimentaires récents de l'Eventail celtique. Océanologica Acta 23 (1), 109-116.

Belderson, R.H., Pingree, R.D., Griffiths, D.K., 1986. Low sea-level tidal origin of Celtic sea sand banks- Evidence from numerical modelling of M2 tidal streams. Mar. Geol. 73, 99-108.

Berné, S., Lericolais, G., Marsset, T., Bourillet, J.F., Debatist, M., 1998. Erosional offshore sand ridges and lowstand shorefaces: Examples from tide- and wave-dominated environments of France. J. Sediment. Res. 68 (4), 540-555.

Berthois, L., Duprat, J., Gonthier, E., Pujol, C., Pujos-Lamy, A., 1973. Résultats préliminaires de l'étude effectuée par l'I.G.B.A., concernant la mission GEOGAS (5 au 17 novembre 1972) au Nord-Ouest du Golfe de Gascogne. Bull. Inst. Geol. Bassin d'Aquitaine 14, 43-177.

Bouma, A.H., 1962. Sedimentology of Some Flysch Deposits: a Graphic Approach to Facies Interpretation, Elsevier, Amsterdam $168 \mathrm{pp}$.

Bouma, A.H., 1985. Mississippi Fan, Gulf of Mexico. In: Bouma, A.H., Normark, W.R., Barnes, N.E. (Eds.). Submarine Fans and Related Turbidite Systems, Springer, pp. 143-150.

Bouma, A.H., Coleman, J.L., Stelting, C.E., Kohl, B., 1989. Influence of relative sea level changes on the construction of the Mississippi Fan. Geo-Mar. Lett. 9, 161-170.

Bourillet, J.F., Loubrieu, B., 1995. Atlantique Nord-Est, Bathymorphologie de la Marge des Entrées de la Manche. Editions IFREMER.

Broecker, W., Kennett, J.P., Flower, B.P., Teller, J.T., Trumbore, S., Bonami, G., Wolfli, W., 1989. Routing of meltwater from the Laurentide Ice Sheet during the Younger Dryas cold episode. Nature 341, 318-321.

Cremer, M., 1982. Sédimentation quaternaire de l'éventail subaquatique du Cap-Ferret. Bull. Inst. Geol. Bassin d'Aquitaine 31, 73-88.

Cremer, M., Orsolini, P., Ravenne, C., 1985. Cap-Ferret Fan, Atlantic Ocean. In: Bouma, A.H., Normark, W.R., Barnes, N.E. (Eds.). Submarine Fans and Related Turbidite Systems, Springer, Berlin, pp. 113-120.

Damuth, J.E., 1975. Echo-character of the western equatorial Atlantic floor and its relationship to the dispersal and distribution of terrigenous sediments. Mar. Geol. 18, 17-45.

Damuth, J.E., 1977. Late quaternary sedimentation in the western equatorial Atlantic. Geol. Soc. Am. Bull. 88, 695-710.

Damuth, J.E., 1980. Use of high-frequency $(3.5-12 \mathrm{kHz})$ echograms in the study of near-bottom sedimentation processes in the deep-sea: a review. Mar. Geol. 38, 51-75.

Damuth, J.E., Hayes, D.E., 1977. Echo character of the east Brazilian Continental Margin and its relationship to sedimentary processes. Mar. Geol. 24, 73-95.

Damuth, J.E., Flood, R.D., 1985. Amazon Fan, Atlantic Ocean. In: Bouma, A.H., Normark, W.R., Barnes, N.E. (Eds.). Submarine Fans and Related Turbidite Systems, Springer, Berlin, pp. 97-106.

Damuth, J.E., Flood, R.D., Kowsmann, R.O., Belderson, R.H., Gorini, M.A., 1988. Anatomy and growth pattern of Amazon deep-sea fan as revealed by long- range side- scan sonar 
(GLORIA) and high-resolution seismic studies. A.A.P.G. Bull. 72 (8), 885-911.

Droz, L., Rigaut, F., Cochonat, P., Tofani, R., 1996. Morphology and recent evolution of the Zaire turbidite system (Gulf of Guinea). Geol. Soc. Am. Bull. 108 (3), 253-269.

Droz, L., Auffret, G.A., Savoye, B., Bourillet, J.F., 1999. L'éventail profond de la marge Celtique: stratigraphie et évolution sédimentaire. C.R. Acad. Sci. Paris 328, 173-180.

Duplessy, J.C., Delibrias, G., Turon, J.L., Pujol, C., Duprat, J., 1981. Deglacial warming of the Northeastern Atlantic ocean: correlation with the paleoclimatic evolution of the European continent. Palaeogeogr. Palaeoclimatol. Palaeoecol. 35, 121-144.

Fairbanks, G., 1989. A 17,000-year blacio-eustatic sea level record/ influence of glacial melting rates on the Younger Dryas event and deep-ocean circulation. Nature 342, 637-642.

Flood, R.D., Piper, D.J.W., 1997. Amazon fan sedimentation: the relationship to equatorial climate change, continental denudation, and sea-level fluctuations. In: Flood, R.D., Piper, D.J.W., Klaus, A., Peterson, L.C. (Eds.), Proceeding of the Ocean Drilling Program, Scientific Results, pp. 653-675.

Gibbard, P.L., 1988. The history of great northwest European rivers during the past three millions years. Phil. Trans. R. Soc. London B318, 559-602.

Johnson, M.A., Kenyon, N.H., Belderson, R.H., Stride, A.H., 1982. Sand transport. In: Stride, A.H. (Ed.). Offshore Tidal Sands, Processes and Deposits, Chapman \& Hall, London, pp. 58-94.

Kenyon, N.H., Stride, A.H., 1970. The tide-swept continental shelf sediments between the Shetland Isles and France. Sedimentology 14, 159-173.

Kenyon, N.H., Belderson, R.H., Stride, A.H., 1978. Channels, canyons and slump folds on the continental slope between South-West Ireland and Spain. Oceanol. Acta 1 (3), 369-380.

Kenyon, N.H., Amir, A., Cramp, A., 1995. Geometry of the younger sediment bodies of the Indus Fan. In: Pickering, K.T., Hiscott, R.N., Kenyon, N.H., Ricci Lucchi, F., Smith, R.D.A. (Eds.). Atlas of Deep Water Environments: Architectural Style in Turbidite Systems, Chapman \& Hall, London, pp. 89-90.

Kolla, V., Coumes, F., 1987. Morphology, internal structure, seismic stratigraphy, and sedimentation of Indus fan. A.A.P.G. Bull. 71 (6), 650-677.

Le Suavé, R., 2000. Synthèse bathymetrique et imagerie acoustique. Zone économique exclusive (ZEE). Atlantique Nord-Est, Brest, Editions IFREMER.

Lericolais, G., 1997. Evolution du Fleuve Manche depuis l'Oligocène: Stratigraphie et Géomorphologie d'une Plateforme Continentale en Régime Périglaciaire. Thèse de 3e cycle (thesis), Université de Bordeaux I, 265 pp.

Lericolais, G., Auffret, J.P., Bourillet, J.F., Berné, S., Guennoc, P., Le Drezen, E., Normand, A., Guillocheau, F., 1995. L'énigmatique fosse centrale de la Manche: Une approche de sa morphologie et de son remplissage par géophisique haute résolution. C. R. Acad. Sci. Paris IIA, 39-46.

Loncaric, N., Auffret, G.A., Abrantes, F., Baas, J.H., Gaspar, L., Pujol, C., 1998. Late Quaternary sedimentation patterns on the Meriadzek Terrace, Bay of Biscay (ESSCAMP 02 core: $47^{\circ} \mathrm{N}$ $\left.9^{\circ} \mathrm{W}\right)$. Mar. Geol. 152, 57-73.

Marsset, T., Tessier, B., Reynaud, J.Y., Debatist, M., Plagnol, C.,
1999. The Celtic Sea banks: an example of sand body analysis from very high-resolution seismic data. Mar. Geol. 158, 89-109.

Martinson, D.G., Pisias, N.G., Hays, J.D., Imbrie, J., Moore, T.C., Shackleton, N.J., 1987. Age dating and the orbital theory of the ice ages: development of a high-resolution $0-300,000$ year chronostratigraphy. Quat. Res. 27, 1-30.

McCabe, M., Clark, P.U., 1998. Ice sheet variability around the North Atlantic Ocean during the last deglaciation. Nature 392, 373-377.

Migeon, S., Weber, O., Faugeres, J.C., Saint-Paul, J., 1999. SCOPIX: A new imaging system for core analysis. Geo-Mar. Lett. 18, 251-255.

Nakajima, T., Satoh, M., Okamura, Y., 1998. Channel-levee complexes, terminal deep-sea fan and sediment wave fields associated with the Toyama Deep-Sea Channel system in the Japan Sea. Mar. Geol. 147 (1-4), 25-41.

Nelson, C.H., Twichell, D.C., Schwab, W.C., Lee, H.J., Kenyon, N.H., 1992. Upper Pleistocene turbidite sand beds and chaotic silt beds in the channelized, distal, outer-fan lobes of the Mississippi fan. Geology 20, 693-696.

Normark, W.R., Damuth, J.E., 1997. Sedimentary facies and associated depositiona elements of the Amazon Fan. In: Flood, R.D., Piper, D.J.W., Klaus, A., Peterson, L.C. (Eds.), Proceeding of the Ocean Drilling Program, Scientific Results, pp. 611-651.

Normark, W.R., Piper, D.J.W., Hiscott, R.N., 1998. Sea level controls on the textural characteristics and depositional architecture of the Hueneme and associated submarine fan systems, Santa Monica Basin, California. Sedimentology 45 (1), 53-70.

Pickering, K.T., Stow, D.A.V., Watson, M., Hiscott, R.N., 1986. Deep-water facies, processes and models: a review and classification scheme for modern and ancient sediments. Earth Sci. Rev. 23, 75-174.

Piper, D.J.W., 1970. Transport and deposition of holocene sediment on La Jolla Deep Sea Fan, California. Mar. Geol. 8, 187-210.

Piper, D.J.W., Normark, W.R., 1983. Turbidite depositional patterns and flow characteristics, Navy Submarine Fan, California Borderland. Sedimentology 30, 681-694.

Piper, D.J.W., Savoye, B., 1993. Process of late quaternary turbidity current flow and deposition on the Var deep-sea fan, north-west Mediterranean sea. Sedimentology 40 (3), 557-583.

Posamentier, H.W., Erskine, R.D., Mitchum, R.M.J., 1991. Models for submarine-fan deposition within a sequence-stratigraphic framework. In: Weimer, P., Link, M.H. (Eds.). Seismic Facies and Sedimentary Processes of Submarine Fans and Turbidite Systems, Springer, New York, pp. 127-136.

Pujol, C., 1980. Les foraminifères planctoniques de l'Atlantique Nord au Quaternaire. Ecologie-Stratigraphie-Environnement. Mem. Inst. Geol. Bassin d'Aquitaine 10, 1-254.

Reading, H.G., Richards, M., 1994. Turbidite Systems in DeepWater Basin Margins Classified by Grain Size and Feeder System. A.A.P.G. Bull. 78, 792-822.

Reid, G.S., Hamilton, D., 1990. A reconnaissance survey of the Whittard Sea Fan, Southwestern Approaches, British Isles. Mar. Geol. 92, 69-86.

Reynaud, J.Y., Tessier, B., Proust, J.N., Dalrymple, R., Bourillet, 
J.F., Debatist, M., Lericolais, G., Berne, S., Marsset, T., 1999a. Architecture and sequence stratigraphy of a late Neogene incised valley at the shelf margin, southern Celtic Sea. J. Sediment. Res. 69 (2), 351-364.

Reynaud, J.Y., Tessier, B., Proust, J.N., Dalrymple, R., Marsset, T., DeBatist, M., Bourillet, J.F., Lericolais, G., 1999b. Eustatic and hydrodynamic controls on the architecture of a deep shelf sand bank (Celtic Sea). Sedimentology 46 (4), 703-721.

Reynaud, J.Y., Tessier, B., Berne, S., Chamley, H., Debatist, M., 1999c. Tide and wave dynamics on a sand bank from the deep shelf of the Western Channel approaches. Mar. Geol. 161 (2-4), 339-359.

Reynaud, J.Y., Lauriat-Rage, A., Tessier, B., Néraudeau, D., Braccini, E., Carriol, R.P., Clet-Pellerin, M., Moullade, M., Lericolais, G., 1999d. Importation et remaniements de thanatofaunes dans les sables de la plate-forme profonde des approches occidentales de la Manche. Oceanol. Acta 22 (4), 381-396.

Schwab, W.C., Lee, H.J., Twichell, D.C., Nelson, C.H., McArthur, W.G., Kenyon, N.H., 1996. Sediment mass-flow processes on a depositional lobe, outer Mississippi Fan. J. Sediment. Res. 66 (5), 916-927.

Shanmugam, G., Moiola, R.J., 1991. Types of Submarine Fan Lobes: Models and Implications. A.A.P.G. Bull. 75 (1), 156179.

Shanmugam, G., Moiola, R.J., Damuth, J.E., 1985. Eustatic control of submarine fan development. In: Bouma, A.H., Normak,
W.R., Barnes, N.E. (Eds.). Submarine Fans and Related Turbidite Systems, Springer, New York, pp. 23-28.

Sibuet, J.C., Monti, S., Pautot, G., 1994. Carte bathymétrique du Golfe de Gascogne. C. R. Acad. Sci. Paris 318 (2), 615-625.

Stow, D.A.V., Howell, D.G., Nelson, H.C., 1985. Sedimentary, tectonic, and sea-level controls. In: Bouma, A.H., Normark, W.R., Barnes, N.E. (Eds.). Submarine Fans and Related Turbidite Systems, Springer, New York, pp. 15-22.

Stow, D.A.V., Reading, H.G., Collinson, J.D., 1996. Deep seas. In: Reading, H.G. (Ed.). Sedimentary Environments: Processes, Facies and Stratigraphy, Blackwell Science, Oxford, pp. 395453.

Stuiver, M., Reimer, P.J., Bard, E., Beck, J.W., Burr, G.S., Hughen, K.A., Kromer, B., McCormac, G., van der Plicht, J., Spurk, M., 1998. INTCAL98 Radiocarbon Age Calibration, 24,000-0 cal BP. Radiocarbon 40 (3), 1041-1083.

Twichell, D.C., Kenyon, N.H., Parson, L.M., McGregor, B.A., 1991. Depositional patterns of the Mississippi Fan surface: evidence from GLORIA II and high-resolution seismic profiles. In: Weimer, P., Link, M.H. (Eds.). Seismic Facies and Sedimentary Processes of Submarine Fans, Springer, New York, pp. 349-363.

Weimer, P., 1990. Sequence stratigraphy, facies geometries, and depositional history of the Mississippi fan, Gulf of Mexico. A.A.P.G. Bull. 74 (4), 425-453. 